ROCZNIKI HUMANISTYCZNE

Tom LXVIII, zeszyt 1 - 2020

DOI: http://dx.doi.org/10.18290/rh20681-3

\title{
EWA CYBULSKA-BOHUSZEWICZ
}

\section{„Z KAŻDEGO STWORZENIA \\ UMIAŁ SIĘ KU WIĘTSZEJ MIŁOŚCI BOSKIEJ POBUDZIĆ”: ZWIERZĘTA JAKO PRZYJACIELE SŁUG BOŻYCH (NA PODSTAWIE ŻYWOTÓW ŚWIĘTYCH PIOTRA SKARGI)}

Zwierzęta są symbolami pryncypiów i sił kosmicznych, materialnych i duchowych ${ }^{1}$. \begin{abstract}
Pamięci Profesora Franciszka Pepłowskiego, który byt miłośnikiem
\end{abstract} wszelkich bestyj: tych fikcyjnych (literackich) $i$ tych rzeczywistych.

W niniejszym artykule zamierzam rozwinąć refleksję na temat obecności motywów zwierzęcych w Żywotach świętych Piotra Skargi. Po raz pierwszy zwróciłam na nie uwagę w pracy poświęconej zoomorficznym inkarnacjom szatana we wzmiankowanym zbiorze ${ }^{2}$. Teraz chciałabym przedstawić te sceny Skargowego operis, gdzie stworzenia te nie są wysłannikami sił nieczystych, ale - przeciwnie - odgrywają pozytywną rolę. Z metodologicznego punktu widzenia, podobnie jak w poprzednim studium, nawiązuję do ustaleń tzw. śląskiej szkoły mikrologii. Badacze skupieni wokół tego projektu przyjmowali, że warto badać nie tylko te części dzieła literackiego, które powszechnie uznawane są za najbardziej istotne, ale i należy pochylać się nad

Dr Ewa Cybulska-BohuszewiCZ - adiunkt Pracowni Słownika Polszczyzny XVI wieku, IBL PAN w Warszawie; e-mail: ewa.cybulska@ibl.waw.pl

1 J. Chevalier, A. Gheebrant, Dictionaire des symboles: mythes, rêves, coutumes, gestes, formes, figures, coloreurs, nombres, Paryż 1982, s. 15.

2 Praca ta ukaże się w czasopiśmie „Terminus” (2/2019). 
tym, co poślednie ${ }^{3}$ - a tak przez długie lata postrzegano wątki cudowne w dziele jezuity. Mikrolodzy proponują badać drobne, zdałoby się niepozorne, cząstki dzieła (nazywają je „miniaturami”). Spojrzenie na utwór od tej strony (a zatem badanie fragmentów, motywów, „odprysków”) pozwala odkryć treści, do których trudno dotrzeć w inny sposób, a które bywają (zwyczajnie) niewidoczne w skali „makro”. Przypomina to pracę średniowiecznych skrybów-miniatorów, którzy poprzez skupienie się na detalu (takim jak np. sentencja, myśl, pojęcie) odkrywali istotę tekstu:

[...] etymologia tytułowego terminu [tj. słowa „miniatura” - E. C-B] wbrew pozorom nie wywodzi się od łacińskiego przymiotnika minimus (mały), lecz od „minii” (tlenek ołowiu), czerwonego barwnika, którym średniowieczni miniatorzy wypisywali najważniejsze partie tekstu, teologiczne pojęcia, ważne myśli i symbole. Gotycka miniatura, nie oznaczała dziełka o skromnych rozmiarach, lecz istotność, a nawet wyjątkowość samego komunikatu ${ }^{4}$.

W Żywotach znajdujemy tego rodzaju „miniaturowe” komunikaty. Część z nich to właśnie symboliczne bądź dosłowne portrety zwierząt, podporządkowane w tekście większym całościom narracyjno-kompozycyjnym, jakimi są miracula. Bestie występują w nich bądź w aspekcie negatywnym (co opisałam w poprzednim tekście), bądź w pozytywnym (co jest przedmiotem tej pracy). W każdym z tych ujęć figury teriomorficzne są nośnikami określonych informacji dotyczących spraw prymarnych np. ontologii oraz natury dobra i zła, miejsca człowieka we wszechświecie. Zwierzęta są też alegorycznymi wzorcami pewnych ludzkich zachowań i postaw. Jak konstatuje Wiesław Przybyła: „obrazy zwierząt w wytworach kultury niemal nigdy nie mają charakteru autotelicznego, lecz są swoistym medium dla ludzi”. Badacz przywołuje także poglądy Klaudiusza Deverta, który przyjmował, że nasze zainteresowanie zwierzętami wynika $\mathrm{w}$ istocie $\mathrm{z}$ chęci poznania ludzkiej natury, jest jednym ze źródeł autoidentyfikacji ${ }^{5}$, zaś „w kulturowej semantyce zwierząt niczym

\footnotetext{
${ }^{3}$ A. NAwAReCKI, [wstęp do:] Miniatura i mikrologia literacka, t. II, red. A. Nawarecki, Katowice 2000, s. 8; TEGOŻ, O ślaskiej szkole mikrologii (1999-2005). Garść wspomnień, „Forum Poetyki” 2017, s. 13, http://fp.amu.edu.pl/o-slaskiej-szkole-mikrologii-1999-2005-garscwspomnien/; zob. też tomy zbiorowe: Miniatura i mikrologia literacka, t. I-III., red. A. Nawarecki, Katowice 2000-2003 oraz Skala mikro w badaniach literackich, red. A. Nawarecki, M. Bogdanowska, Katowice 2005.

${ }^{4}$ A. NAWARECKI, [Wstęp do:] Miniatura, s. 8.

5 W. PrzYbyŁA, Kulturowa semantyka motywu zwierzat, „Teksty Drugie” 2011, nr 3, s. $238-252$.
} 
w zwierciadle odbija się spolaryzowana mozaika człowieka wobec otoczenia"6. Podobne wnioski pojawiały się już we wcześniejszych pracach antropologicznych i etnologicznych Claude'a Lévi-Straussa ${ }^{7}$.

Figury zwierząt $\mathrm{w}$ dziele tak obszernym, jakim są Żywoty, pojawiają się dość często. Wspominałam już w pierwszym tekście im poświęconym, iż ze względu na ich ilość, a także zróżnicowany sposób przedstawiania, trudno jest dokonać jakiegoś konkretnego podziału owych wątków. Ma to swoje źródło między innymi w wieloznacznej wymowie symbolu - jego (jak zauważył Przybyła): „multiwariantowości i diachroniczności”:

Ogrom różnych ujęć tych samych nawet gatunków zwierząt nie pozwala tak naprawdę na ustalenie zbyt wielu aksjomatów. Wiedzą o tym dobrze autorzy leksykonów symboli, generujących znaczenia, eksplikacje i egzemplifikacje w porządku równorzędności i ekskluzji, nie zaś w układzie synonimicznym. Sąd Doroty Römhild brzmi zatem jak odarcie zooestetyki z wszelkich złudzeń: „Albowiem ambiwalencja literackiego świata zwierząt, która rozciąga się od demonicznych fantazji strachu do projektów życzeniowych, od pojęcia bestii do moralnego wywyższania czworonożnych przyjaciół, nie pozwala się wtłoczyć w żaden porządkujący schemat leksykalny ${ }^{8}$.

Oczywiście muszę się zgodzić z powyższymi obserwacjami. Niemniej jednak, ponieważ pracę naukową winien cechować pewien porządek i dążenie do tego, by dane zjawisko pokazać w sposób nie tylko ogólny, ale możliwie szczegółowy (co zresztą jest głównym postulatem przyjętej przeze mnie metodologii), postanowiłam, iż w studium tym materia zostanie uporządkowana w sposób następujący: w części pierwszej zostaną zaprezentowane motywy zwierzęce związane z symbolicznym i alegorycznym, też: metaforycznym sposobem ich przedstawiania. Część druga będzie zawierała opis zwierząt jako takich. Ten porządek został wspomniany już w pierwszym szkicu o demonicznych reprezentacjach zwierząt w Żywotach. Sądzę, że konsekwentne stosowanie tego podziału również i w tym wypadku nada całości pracy jednolity, a dzięki temu spójny charakter. Wydaje się zresztą, iż takie uporządkowanie materiału jest w przypadku analizowanego tekstu najbardziej uzasadnione. Podział dychotomiczny pozwala posegregować motywy zwierzęce według nadrzędnych kategorii: obrazy symboliczne/alegoryczne/metaforyczne

\footnotetext{
${ }^{6}$ Tamże, s. 241.

${ }^{7}$ C. LÉVI-Strauss, Totemizm, przeł. A. Steinsberg, Warszawa 1968, s. 135.

${ }^{8}$ W. PRZYBYŁA, Kulturowa semantyka, s. 243-244.
} 
versus obrazy nie-symboliczne/nie-alegoryczne/nie-metaforyczne ( $\mathrm{tj}$. dosłowne), i dokonywać w obrębie tych dwóch grup bardziej szczegółowych analiz.

W Żywotach zwierzęta mogą występować jako symbole bądź alegorie związane z osobami uprzywilejowanymi przez Boga. Ambicją świętych, zwłaszcza zaś eremitów, było dążenie do tego, aby przywrócić człowieka naturze. W pismach Ojców Kościoła znajdujemy ślady tych właśnie aspiracji. Jako przykład mogą służyć liczne komentarze do biblijnej Księgi Rodzaju, zwłaszcza zaś jej pierwszej części, poświęconej aktowi stworzenia świata. W interesującym nas kontekście na szczególną uwagę zasługują dzieła takie jak Hexaemeron św. Ambrożego czy wcześniejszy zbiór pod tym samym tytułem autorstwa św. Bazylego. Mimo zależności dzieła Ambrożego od Bazylego chciałabym więcej miejsca poświęcić temu pierwszemu, gdyż Hexaemeron Bazylego wyrasta bardziej z ducha polemiki względem starożytnych poglądów na temat genesis, zaś u Ambrożego rozwinięta została refleksja nad światem flory i fauny, konkretnie jego interpretacja alegoryczna ${ }^{9}$. Zwierzęta występują w owych homiliach przede wszystkim jako alegorie i symbole określonych postaw, np. miłości rodzicielskiej, wierności, czujności itp. Święty uznawał cały świat przyrody ożywionej (także rośliny) za byty, które mogą przemawiać do człowieka. Kazania z jego Hexaemeronu można uznać za jedną $\mathrm{z}$ aktualizacji toposu świata-księgi (liber mundi), którą Stwórca przeznaczył do odczytywania człowiekowi. Bardzo trafnie ideę tę wyraził Alan z Lille w zwięzłym wierszyku:

Omnis mundi creatura quasi liber et pictura

nobis est et speculum: nostrae vitae, nostrae mortis, nostri status, nostrae sortis fidele signaculum ${ }^{10}$.

9 A. AlEKsIEJUK, „Homilie na sześć dni stworzenia” świętych Bazylego Wielkiego i Ambrożego z Mediolanu: przyczynek do analizy porównawczej „Hexaemeronów”, „Acta Patristica” 9(2018), z. 18, s. 56-7; M. SIMONETTI, Między dostownościa a alegoria. Przyczynek do historii egzegezy patrystycznej, przeł. T. Skibiński, Kraków 2000, s. 108-347 (rozdziały o koncepcji figuratywnego odczytywania Pisma od Euzebiusza, poprzez Ojców Kapadockich, aż do IV wieku).

${ }^{10}$ Cyt. za: M. HANUSIEWICZ, Święte $i$ zmystowe $w$ poez.ji religijnej polskiego baroku, Lublin 1998, s. 36. O toposie świata-księgi pisałam obszernie w monografii „On utwierdzit na wieki niebo niestanowne”. Chrześcijańska wizja kosmosu w poezji polskiej (od połowy XVI do połowy XVIII w.), Warszawa 2010, rozdział II: Chrystianizacja starożytnych koncepcji uniwersum, s. $85 \mathrm{n}$. 
Rozwijał ją w swych pismach (Breviloquium, Collationes in Hexaemeron) św. Bonawentura, który twierdził wprost, iż w stworzeniu można dostrzec ślady (vesigia) pozostawione przez Boga ${ }^{11}$. U Ambrożego, jak i u wspomnianych wyżej następców, uniwersum jawi się jako całość doskonała, harmonijnie zaprojektowana przez Boga. Oczywiście jest tu miejsce na zło (wskutek upadku człowieka). Przejawia się ono przede wszystkim w przemijalności napełniających świat stworzeń (wanitatywny charakter doczesnego świata św. Ambroży eksponuje najczęściej za pomocą spetryfikowanej, obecnej już w Biblii, symboliki roślin - trawy czy kwiatów) oraz w agresji, konieczności zabijania po to, żeby utrzymać swoje życie, ale i spowodowanej łakomstwem czy chciwością (co można łatwo zaobserwować szczególnie w świecie zwierząt, ale i w obrębie ludzkiego continuum) ${ }^{12}$. Jaka nauka płynie dla jednostki kontemplującej taką właśnie przestrzeń: z jednej strony - doskonałą, harmonijna, z drugiej zaś - w jakiś sposób ułomną, zniszczoną przez grzech? Otóż, jak poucza Ambroży, rozważanie zarówno dobra, które istnieje w świecie i manifestuje się przede wszystkim poprzez harmonijny układ jego elementów, jak i zła (np. wzajemne pożeranie się zwierząt) prowadzić może do zbudowania moralnego człowieka. Poprzez obcowanie z dobrem ma on okazję w niemalże bezpośredni sposób zetknąc się ze Stwórcą świata, obecnym we wszystkim tym, co - jak konstatuje Biblia - „było dobre” już w chwili powstania. Zetknięcie zaś ze złem ma z jednej strony przypominać o mizerii ludzkiej kondycji, grzechu, z drugiej zaś - czynić jednostkę zdolną do jego przełamywania. Każdorazowe spotkanie ze złem jest też zachętą do kształtowania siebie: zwalczania w sobie próżności, agresji, pychy itd. Refleksje na ten temat ujęte zostały przez Ambrożego w formie opisów różnych stworzeń. Święty uważał, iż człowiek nie może poznać siebie samego, jeśli wpierw nie pozna zwierząt, dlatego prezentuje szerokie spektrum animalnych portretów, by zapewnić odbiorcom efektywne studia nad księga natury ${ }^{13}$. Znajdziemy więc w zwierzyńcu kaznodziei bociana - popularną alegorię miłości dzieci względem rodziców ${ }^{14}$, ryby, chroniące $\mathrm{w}$ pyszczkach swą ikrę i narybek

\footnotetext{
11 Bonawentura, O stworzeniach świata, tłum. M. Olszewski, w: Wszystko to ze zdziwienia. Antologia tekstów filozoficznych z XIII wieku, wybór, oprac. K. Błachowicz, Warszawa 2002, s. 103 n (zwłaszcza s. 123-125).

${ }^{12}$ B. ZgRaja, Stworzenia nierozumne wezwaniem do doskonatości. Przyczynek do studium nad „Hexaemeronem” św. Ambrożego, „Vox Patrum” 32(2012), t. 57, s. 821-836.

${ }^{13}$ W. PRZYBYŁA, Kulturowa semantyka, s. 240.

14 Sylwetka bociana była popularna także w piśmiennictwie polskim: „Bocian jest ptak lutościwy, bo gdy starym bocianom skrzydła wypadają, tedy młodszy żywią je tak długo, aż ich skrzydła moc wezmą", zob. S. FALIMIRZ, $O$ ziołach i o mocy ich, Kraków 1534, cz. IV,
} 
przed drapieżcami (wzór postawy rodzicielskiej), ale także murenę i żmiję, które - choć okrutne, to również mogą służyć za przykład np. wytrwania w małżeństwie mimo ,jadowitego" charakteru współmałżonka.

Takie teksty jak Hexaemeron (czy to autorstwa Bazylego czy Ambrożego) ukazują, w jaki sposób kształtował się chrześcijański pogląd na świat przyrody, jaki status w filozofii chrześcijańskiej przypisywano zwierzętom. Wbrew obiegowym opiniom (popularnym zwłaszcza w ostatnim czasie) Kościół nie uzurpował sobie prawa do tego, by z człowieka czynić władcę świata ${ }^{15}$, co miało być równoznaczne $\mathrm{z}$ tym, iż może przekształcać daną mu przez Boga przestrzeń w sposób dowolny, czy też wykorzystywać inne stworzenia wyłącznie na swoją korzyść. Biblijna fraza: „czyńcie sobie ziemię poddaną” nie jest dziś rozumiana właściwie ${ }^{16}$. U zarania dziejów Stwórca powierzył człowiekowi władzę nad innymi bytami (co wyraża się przede wszystkim w scenie nadawania im imion przez Adama, nie zaś przez Boga). Nie znaczy to jednak, iż panowanie nad zwierzętami miało oznaczać podporządkowanie ich sobie, czy - co gorsza - krzywdzenie, zabijanie i zjadanie ich ${ }^{17}$. W Raju wszyscy byli wegetarianami: nie tylko człowiek, ale i drapieżniki (lew, wilk itp.). Dopiero grzech zmienił ten stan rzeczy. Wzajemne pożeranie się poszczególnych gatunków jest więc wynikiem upadku natury. Ucierpiał na tym także człowiek: dotąd nieśmiertelny, zaczął podlegać śmierci. Ponadto (miało to miejsce już po potopie) życie ludzkie zostało skrócone i to wtedy człowiek stał się drapieżnikiem. W Piśmie możemy przeczytać jednak, że ta sytuacja jest przejściowa: nadejdą czasy mesjańskie, kiedy doskonałość zostanie przywrócona, lew będzie bawił się z barankiem, zaś niemowlę z kobrą.

Ojcowie Kościoła i liczni święci próbowali nieco przyspieszyć ów zbawczy moment, kiedy na powrót zapanuje harmonia między wszystkimi zapełniającymi uniwersum bytami. Wielu Bożych wybrańców wykazuje żywe zainteresowanie „braćmi mniejszymi” - zwierzętami. Nie dotyczy to li tylko św. Franciszka z Asyżu, który jest szczególnie znany ze swego umiłowania tych istot, ale i innych świętych osób, których związki ze zwierzętami są warte opisania.

\footnotetext{
s. 20c. Podobnie opisuje je także M. Rej (zob. Źwierzyniec, Kraków 1562, 20v) czy Marcin Bielski w Kronice wszystkiego świata (Kraków 1564, s. 298v).

${ }^{15}$ Choć oczywiście był on uznawany za „koronę stworzenia”, a wyrastało to z przekonania, iż w bycie ludzkim zawierają się obraz i podobieństwo Boże.

16 Zob. M. KWAPISZEWSKA-ANTAS, Człowiek wobec zwierzat na przestrzeni dziejów, „Słupskie Studia Filozoficzne” 2007, nr 6, s. 97-99.

${ }^{17}$ Zob. P. JASKÓŁA, Bóg rzekt i stało się. Zarys patrologii, Opole 2018, s. 22. Autor posługuje się określeniem „misja powiernicza”, gdy mówi o umieszczeniu człowieka w Raju.
} 
Zanim to jednak uczynię, warto jeszcze krótko nadmienić, jak sam autor Żywotów, ksiądz Skarga, widział te sprawy. Otóż - już we wstępnej części swego dzieła stwierdza on coś, co współczesnym odbiorcom może wydać się zaskakujące, bo bardzo nowoczesne. Jezuita potępia bowiem bezmyślne zabijanie zwierząt, uznaje „bestyje” za istoty czujące, podkreśla, iż nie takim (tj. nie drapieżcą) został stworzony człowiek. Odbieranie życia innym stworzeniom kaznodzieja określa wprost jako nieludzkie: „bo wprawdzie i zwierzę zabić coś jest mało ludzkiego, gdy widzisz, jako nie rado żywota traci"18. Skarga postrzega przelewanie krwi (każdej - czy to ludzkiej, czy też zwierzęcej) jako coś, co nie powinno mieć miejsca, a na co zezwolił Bóg wyłącznie ze względu na słabość człowieka. Widok krwi zabijanych zwierząt napawa ludzi lękiem. Jak twierdzi kaznodzieja - nie dzieje się tak bez przyczyny. Człowiek ,niejakie okrucieństwo nad nimi czyniąc [...] oduczając się niejako w mordowaniu zwierząt miłosierdzia", winien pamiętać, że każdy akt pozbawienia życia jest złem. „Oduczeni miłosierdzia” ludzie ośmielają się bowiem nie tylko uśmiercać zwierzęta, ale także pozbawiać życia swoich bliźnich, co jest największym przewinieniem, gdyż wiąże się z unicestwieniem Bożego obrazu i podobieństwa. Nakaz Stwórcy, aby „krwie bydlęcej”"19 nie „pożywać" ${ }^{20}$ respektują prawie wszyscy bohaterowie przedstawieni w dziele Skargi (szczególnie eremici). Czasem zdarzają się wyjątki: niektórzy konsumują ryby, ale i to rzadko, w sytuacjach wyjątkowych: np. św. Tomasz z Akwinu, złożony ciężką chorobą, zapragnął tuż przed śmiercią zjeść śledzia takiego, jakiego niegdyś podano mu w Paryżu. Ostatecznie jednak nie uczynił tego i oddał ducha, pożywiając się Chlebem Eucharystycznym [SkarŻyw 202]. Jeszcze bardziej surowa była Maria z Egniej, która zjedzenie mięsa uważała

18 P. SKARGA, Żywoty świętych, Wilno 1579, s. 202. Wszystkie cytaty z dzieła Skargi pochodzą z tego wydania; lokalizuję je poprzez podanie skrótu SkarŻyw i numeru strony.

${ }^{19}$ Słowo „krew” należy tu rozumieć przenośnie: jako „siedlisko życia”, też: istotę żywą w ogóle. Zob. hasło krew w Słowniku polszczyzny XVI wieku (wersja elektroniczna): http://spx vi.edu.pl/indeks/haslo/59774.

${ }^{20}$ Bardzo ważne jest tutaj to właśnie konkretne słowo: „pożywać”. W polszczyźnie XVIwiecznej istniały dwa leksemy: ,jeść” i ,pożywać”. Dla człowieka współczesnego ich rozróżnienie jest zasadniczo niemożliwe: dziś są uznawane za synonimy. W staropolszczyźnie jednak różnica semantyczna między tymi leksemami była wyczuwalna i istotna. Polegała mianowicie na tym, iż słowo „pożywać” oznaczało ‘przyjmować pokarm dający życie', zaś ,,jeść” znaczyło tylko: 'przyjmować pokarm, połykać' - zakres tego słowa był ograniczony w zasadzie wyłącznie do czynności fizjologicznej, podczas gdy leksem ,pożywać” oznaczał coś więcej, gdyż wyraz ten zawiera ten sam prasłowiański rdzeń co wyraz „żyć”. Zob. M. MAYENOWA, O kilku staropolskich formach ekspresywnych. Z materiatów „, Stownika polszczyzny XVI w.”, „Pamiętnik Literacki” 1966, nr 4, s. 489. 
za jeden z największych grzechów swego życia. Pobożna niewiasta odbywała doprawdy straszliwą pokutę po tym, kiedy zdarzyło się jej skosztować mięsnego pokarmu. Dodam, iż był to akt jednorazowy:

A pomniąc, iż po jednej ciężkiej niemocy na posilenie zdrowia mięso jadła i wino piła, ostro bardzo to nagradzała. Bo na koniec odrzezywała niektóre mięso z ciała swego, czego byli spowiednicy i te panie, które po śmierci jej ciało obmywały, świadome. Wina nigdy nie piła i mięsa nie jadła [SkarŻyw 580].

Takie drastyczne formy ascezy (tu raczej pokuty) mogą oczywiście wydawać się nieuzasadnione, ale ten przykład klarownie ukazuje, jak bardzo poważnie święci traktowali boskie zalecenia dotyczące właściwej diety. „Włáciwej”, tj. takiej, jaką zaplanował Bóg, gdy stworzył człowieka i umieścił go w Raju. Jak wiemy z Biblii - była ona związana ze spożywaniem wyłącznie pokarmów roślinnych.

Szczególny związek świętych z „braćmi mniejszymi”, wyrastający z przeświadczenia, iż są to byty odczuwające cierpienie i niezasługujące na nie, został zatem w Żywotach wyeksponowany w wielu miejscach i na różne sposoby. Raz jest to wyrażone wprost przez autora przekonanie, iż w odbieraniu życia innym stworzeniom jest „coś mało ludzkiego” i że pozbawia człowieka wrażliwości. Innym razem Skarga opisuje rajską doskonałość, gdzie nie ma miejsca na wzajemne pożeranie się. Wreszcie - święci - „naśliczny obraz Boży" - mięsa po prostu nie jedzą. Zwierzęta w Żywotach mają także wymowę alegoryczną i symboliczną. Tradycja łączenia bestii z poszczególnymi świętymi była popularna już wcześniej, jeszcze zanim Skarga stworzył swoje dzieło (co poświadczają wspomniane działa Ambrożego czy Bazylego). Istniała ponadto, popularna szczególnie w sztukach wizualnych doby średniowiecza, praktyka przedstawiania ich z tzw. atrybutami, stanowiącymi znak rozpoznawczy danego świętego. Skarga nie skupia się na przypisywanych świętym przedmiotom i stworzeniom, dlatego też nie będę rozwijała tego wątku ${ }^{21}$. U jezuity zoomorficzna symbolika ma raczej funkcję ogólną: zwierzęta nie są atrybutami, częściej kaznodzieja posługuje się zwierzęcymi znakami w podobny sposób, w jaki robił to w Hexaemeronie Ambroży. Zwierzę jest zatem alegorią/symbolem jakiejś cnoty, którą dany bohater rozwiną w stopniu imponującym, choć zdarza się, iż określona bestia oznacza świętego jako takie-

${ }^{21}$ Zob. B. SzCZEPANOWICZ, Zwierzęta i rośliny w życiu świętych oraz jako ich atrybuty, Kraków 2007; J. MARECKI, L. ROTTER, Jak czytać wizerunki świętych. Leksykon atrybutów i symboli hagiograficznych, Kraków 2009. 
go: np. z postacią Tomasza z Akwinu łączy Skarga sylwetkę wołu. Jest to związane $\mathrm{z}$ ważnym epizodem $\mathrm{z}$ życia Tomasza (nauka u sławnego mistrza - Wojciecha (Alberta) Wielkiego), który jezuita tak przedstawił w Żywotach:

Uczył się pilno a w milczeniu i cichości, tak, iż go towarzysze [...] niemem wołem zwali, prze milczenie i skromność jego tępy mu rozum przyczytając. Lecz się wkrótce pokazało, gdy z posłuszeństwa na jednę trudną kwestyją odpowiadać musiał, iż za wzywanim pomocy Bożej tak mądrze się wyprawił, iż snadź mało i mistrza nie przechodził. Iż rzekł Wojciech Wielki: „Tomaszu, nie tak na pytanie odpowiadasz, jako urzędu nauczyciela używasz”. I obróciwszy się do uczniów powiedział: „Wy go niemym wołem zowiecie, ale ten wół tak ryknie, iż go świat wszyciek słyszeć będzie" [SkarŻyw 201].

We fragmencie tym symbolika wołu, rzec można, ewoluuje wraz z tokiem narracji. Został on ukazany dwojako: najpierw jest figurą „tępego umysłu”, który współbracia przypisywali Tomaszowi z powodu tego, iż był nadzwyczaj cichy, nie dawał się poznać jako człowiek bystrego rozumu. Rzeczywiście, wół to zwierzę, któremu tradycyjnie nie przypisuje się mądrości. Stworzenie to bywa doceniane z uwagi na swą wytrzymałość, pracowitość, jego cnotą ma być także przysłowiowa pokora, jednak jest też postrzegane jako tępe. Dopiero Albert Wielki w swym proroctwie zmienia tę optykę: Tomasz-wół ma stać się sławnym teologiem, którego głos (,ryk”) usłyszy cały świat. Można tutaj dostrzec podobieństwo do postaci innego świętego - ewangelisty Łukasza, którego atrybutem jest (wedle Apokalipsy) także wół. Ewangelię Łukasza, podobnie jak naukę jego następcy, Akwinaty, cechuje wielka precyzja, szczegółowość opisów, bogactwo detali, staranność w formułowaniu myśli. Widać, że powstawała ona w skupieniu, zaś jej twórca pracował mozolnie, ale i metodycznie, by przedstawione fakty nakreślić w sposób możliwie wierny.

Innym zwierzęciem, które pojawia się na kartach dzieła Skargi i stanowi prefigurację świętego, jest pies. Prefiguruje on Wincentego z Walencji, dominikanina, sławnego kaznodzieję. $Z$ jego narodzinami i wczesnym dzieciństwem łączy się wdzięczna legenda:

Wincencyjusz z Walencyjej [...] jeszcze w żywocie matki znaki swej przyszłej świątobliwości miał. Bo inne ciężko barzo dzieci matka jego rodząc, gdy tym chodziła ani w noszeniu żywota żadnej ciężkości nie miała, ani takiej w rodzeniu trudności użyła. A słyszała często jakoby w żywocie jej szczeniątko szczekało. Co jej duchowny jeden, którego się w tym radziła, wykładał: iż wielkiego kaznodzieję Chrystusowego urodzić miała [SkarŻyw 307-308]. 
Pies jest uznawany za jeden z symboli zakonu kaznodziejskiego dominikanów, nazwanych tak od założyciela - św. Dominika. Nazwa łacińska dominicanes przypadkowo przywołuje dwa słowa: domini oraz canes, co tłumaczy się jako „psy Pana”. Dlatego jednym z symboli zgromadzenia jest czarno-biały pies (takie barwy mają habity zakonników tego zgromadzenia) ${ }^{22}$. W opisywanym żywocie zwierzę to jest ponadto symbolem kaznodziei: ze względu na donośny głos, który odstrasza wrogów (misją „psów Pana” była walka $z$ heterodoksją: albingensami, katarami i waldensami) ${ }^{23}$. Wincenty (zgodnie z poprzedzającą jego narodziny przepowiednią) był jednym ze sławniejszych homiletyków rekrutujących się ze środowiska dominikańskiego. Jak zaświadcza Skarga, organizował on także pielgrzymki, był zaangażowany w ruch pokutny biczowników.

Stworzeniem bardzo często ukazywanym w związku z osobami świętych jest lew. Obecność tego królewskiego zwierzęcia w zastępach Bożych wybrańców może i nie dziwi, należy jednak pamiętać, iż jego symbolika nie jest wcale jednoznacznie pozytywna. Wprawdzie lew łączy się i z postacią Chrystusa (lew Judy), i (podobnie jak wół) z ewangelistami, a konkretnie z osoba Marka, jednak w Nowym Testamencie jest on też symbolem zła - szatana, który ,jak lew ryczący krąży szukając kogo pożreć” (1 P 5,8) ${ }^{24}$. Skarga był świadom owej ambiwalencji i w Żywotach przedstawia króla zwierząt jako demoniczną bestię (np. w żywocie św. Antoniego), ale i jako stworzenie ewokujące boskość. Co więcej, wydaje się, że przedstawień lwa, w których został on ukazany w sposób pozytywny, jest w dziele jezuity więcej. Przymioty dostojnego zwierza wyróżniały papieża Leona $(l e o=$ łac. lew), znanego z niezwykłego daru wymowy. Kaznodzieja przypisuje papieżowi, noszącemu lwie imię, także inne cechy króla zwierząt: mężne serce oraz sprawiedliwość, która jest najważniejszą cechą dobrych władców: Leon zaś sprawował rządy w Kościele w czasach niezwykle trudnych [SkarŻyw 317]. Najbardziej dobitnym tego dowodem jest wspomniany w żywocie epizod, kiedy papież był zmuszony zmierzyć się ze straszliwym Attylą - wodzem Hunów, zwanym

22 G. Ferguson, Signs \& Symbols in Christian Art, London-Oxford 1989, s. 15.

23 Zob. JORDAN Z SAKSONII, Ksiażeczka o poczatkach Zakonu Kaznodziejów, przeł. M. Wylęgała, wstępem i przypisami opatrzył J. Spież, Warszawa 2008; Dominikanie w środkowej Europie w XIII-XV wieku: aktywność duszpasterska i kultura intelektualna, red. J. Kłoczowski, J.A. Spież, Poznań 2002; Dominikanie w czasach krucjat, katedr i herezji, red. T. Gałuszko, M. Karp, Poznań 2016, część wstępna (s. 5 n).

${ }^{24}$ S. KobIElus, Bestiarium chrześcijańskie. Zwierzęta $w$ symbolice i interpretacji: Starożytność i średniowiecze, Warszawa 2002, s. 182. 
„Biczem Bożym”. Skarga plastycznie opisuje spotkanie obu mocarzy. Papież, we wspaniałym odzieniu, $\mathrm{z}$ wielką pompą i majestatem, przemawia do wojownika „słodkiemi słowy”. Ich siła perswazji dorównuje zaiste lwiej mocy: Attyla wycofuje swe oddziały i wraca do Węgier. Co interesujące, ocalenie Rzymu przed Biczem Bożym odnotowują też kronikarze: Maciej z Miechowa i Marcin Bielski. Miechowita pisze o tym zdarzeniu podobnie jak Skarga, posługuje się mianowicie grą słów nawiązującą do „Zwierzęcych” imion mężnych biskupów Rzymu - Leona i Lupusa: „A gdy jego rycerze dziwowali się mówiąc między sobą, iż Atylla nikogo się nie boi na świecie, telko dwojga zwierząk [sic!] Lwa a Wilka, a to żertując z imion dwu biskupów: Lupusa i Leona, dla których i ludu im przepuścił" 25 .

Kolejnym bohaterem, który ukazany został za pomocą opisanych już symboli lwa i psa, jest Piotr z Werony. Jego biografia wyróżnia się na tle innych żywotów, gdyż (w przeciwieństwie do wielu Bożych wybrańców) nie pochodził on z pobożnego chrześcijańskiego domu ${ }^{26}$, wręcz przeciwnie: jego rodzice byli manichejczykami. Szczęśliwie Piotr trafił do chrześcijańskiej szkoły, gdzie się nawrócił i został homiletą znanym ze słownych pojedynków z heretykami. Jak zaświadcza Skarga: „często je [heretyków - E. C-B] na gadanie wyzywał jako lew jaki i wielkiemu się ich pocztu stawiąc" [SkarŻyw 373]. Autor ukazuje tego świętego także jako psa pasterskiego osaczonego przez zgraję wilków (jest to nawiązanie do przypowieści o Dobrym Pasterzu). Ów „pies” umiera jednak pokornie i cicho - jak owca (analogicznie zatem jak Chrystus - Baranek Boży):

Taką jego w Bogu śmiałością i czujnymi postępki gdy zemdleli heretycy, rzucili się do innej rady: postanowili, jako wilcy jadowici, psa owiec Bożych [...] ukąsać i krew jego mieczem rozlać. [...] Zmówili Judasza heretykowie: najęli zdrajcę heretyka, aby go zabił: dali pieniądze krew kupując. I gdy na czas naznaczony sprawy swej z heretyki do Medyjolanu z swego klasztoru z Kumanu [...] jachał, sługa dyjabelski heretyk on przenajęty [...] na onę owieczkę cicha, a broni niemającą, uderzył i w głowę mu kilka ran śmiertelnych zadał [SkarŻyw 373].

Ten typ obrazowania za pomocą par antytetycznych: raz święty został przedstawiony za pośrednictwem figury psa (zwierzę, mimo wszystko - przynaj-

\footnotetext{
25 Zob. M. Miechowita, Polskie wypisanie dwojej krainy świata: która po tatinie [...] Sarmatia [...] zowa, Kraków 1535, s. 57; M. BIELSKI, Kronika wszystkiego świata, Kraków 1564, s. 161.

${ }^{26}$ P. Nehring, Topika wczesnych łacińskich żywotów świętych. Od „Vita Antonii” do „Vita Augustini”, Toruń 1999, s. 67-69.
} 
mniej potencjalnie groźne, bo drapieżne), raz jako baranek (uosobienie łagodności) - pojawia się nie tylko w Żywotach. Złożoną, antytetyczną figurą, ukazującą podwójny aspekt opisywanej osoby, kaznodzieja posługuje się jeszcze w Kazaniach, gdy kreśli portret Chrystusa. W tym dziele jawi się On jako ten, który znosi z cierpliwością grzechy ludzi, ale przy końcu czasów zmieni się w karzącego sędziego. Jezuita przestrzega wiernych, iż „lepiej się teraz z barankiem jednać, niżli się ze lwem potykać" ${ }^{, 27}$. Znów (podobnie jak w żywocie Piotra $\mathrm{z}$ Werony) pojawia się dwoje zwierząt o przeciwstawnych cechach: baranek i lew. Kolejną antytetyczną parę w żywocie Piotra z Werony stanowią też „owieczka cicha” i przedstawieni jako zgraja wilków „heretykowie". Jest to obraz typowy i jednoznaczny w swej wymowie, dlatego też nie wymaga szerszego komentarza.

W opowieści o świętej Teodorze motywy zwierzęce zostały wykorzystane, aby przedstawić niewinność umęczoną. Święta znalazła się w trudnym położeniu, bo nie chciała uczcić pogańskich bożków. Została więc wysłana „do domu nierządnego na stradanie nieuczciwe dziewictwa" [SkarŻyw 341]. Zarówno służebnica Boża, jak i jej adwersarze zostali ukazani za pośrednictwem figur zoomorficznych: „Zbieżeli się ludzie wszeteczni jako jastrząbowie około gołębiczki” [SkarŻyw 341]. Znów (jak powyżej) mamy tutaj konwencjonalny obraz jastrzębi polujących na „gołębiczkę". W tekstach powstałych mniej więcej w tym samym czasie co Żywoty, jastrząb jawi się przede wszystkim jako ptak łowczy, używany do polowania. Chwyta on przede wszystkim gołębie (stąd pospolita nazwa tego ptaka: „gołębiarz”), ale czasem też czyni szkody w gospodarstwie i zagląda do kurnika, by porywać kury. Wierzono, że jego drapieżność miała być tak wielka, iż jakoby nie pije on wody, ale wyłącznie krew upolowanej zwierzyny ${ }^{28}$. Relację między jastrzębiem a jego ofiarami opisał Stanisław Orzechowski, który w Rozmowie albo dyjalogu około egzekucyjej Korony Polskiej stawia go w poczcie z innymi drapieżnikami i pyta retorycznie: „Wilk owcy, jastrząb kokoszy, pies zającowi izali przyrodzonym nieprzyjacielem nie jest?"29. I chociaż dzieło Orzechowskiego ma

${ }^{27}$ P. SKARGA, Kazania, Kraków 1595, s. 7b.

${ }^{28}$ W. KopALIŃSKI, Stownik symboli, Warszawa 2001, s. 117.

${ }^{29}$ S. ORZECHOWSKI, Rozmowa albo dyjalog około egzekucyjej Korony Polskiej, Kraków 1563, s. G3v. Lew - ze wszystkimi swymi przymiotami - był łączony z Chrystusem, zwłaszcza zaś z postacią Chrystusa-Sędziego oraz Chrystusa-Doktora. To ostatnie skojarzenie miało swe źródło w starożytnej ,wiedzy” na temat tego zwierzęcia. Wierzono mianowicie, iż młode lwy przychodzą na świat martwe i ślepe. Po trzech dniach ojciec-lew ożywia je swym tchnieniem i rykiem. Zob. M. BATTISTINI, Astrologia, magia, alchemia. Leksykon historia, sztuka, ikonografia, przeł. E. Morka, Warszawa 2006, s. 48; W. KoPALIŃSKI, Stownik symboli, s. 193. 
zupełnie inną wymowę niż $\dot{Z} y w o t y$, to także i w nim znajdziemy interesujący nas obraz, który - jak już powiedziałam - był skonwencjonalizowany, stąd jego obecność w tekstach przynależących do odmiennych gałęzi staropolskiego piśmiennictwa. Niezależnie od gatunku czy tematyki danego utworu, jastrząb zawsze jest ukazywany jako wróg, napastnik (w przeciwieństwie do innego drapieżcy przestworzy - orła, który konotuje też pozytywne znaczenia $^{30}$ ). Accipiter to (w zasadzie jednoznacznie) agresor, którego nie sposób odeprzeć, gdyż atakuje znienacka: tak portretuja go Rej, Paprocki, Groicki, Kochanowski i inni; chyba tylko wyjątkowo u Stryjkowskiego jawi się jako przeciwnik, którego da się pokonać. Autor Kroniki przytacza stare przysłowie: „Nie trzeba ważyć lekko mdłych nieprzyjacieli, Bo i mdła czapla czasem jastrząba ubije"31. Obok straszliwego jastrzębia u Skargi pojawia się (na zasadzie antytezy) postać „gołębiczki”, której wymowa jest na tyle oczywista, że nie będę rozwijała tego wątku. Poprzestanę na stwierdzeniu, iż w chrześcijaństwie ptak ten był kojarzony z czystością i trzecią osobą Trójcy, a przez to także z duszą ludzką, zamieszkującą ciało, które - zgodnie z literą Pisma - było świątynią Ducha Świętego (1 Kor 6,19-20). Tutaj ptak oznacza oczywiście słabszą od napastników, a przy tym czystą i niewinną Teodorę. W dalszej części omawianego żywotu Skarga przywołuje jeszcze kolejne zwierzęce motywy, w tym wzięty z proroctwa Izajasza $(11,6)$ i powtórzony w Apokalipsie passus o razem pasących się wilku i jagnięciu. Kaznodzieja przetwarza ten wątek na wzór romansowy, czyniąc go częścią epizodu o uratowaniu świętej. Pomoc przychodzi nie tylko niespodziewanie, ale i zaskakujące jest to, kto zostaje wybawicielem dziewicy:

Ledwie modlitwę skończyła, a owo się do niej żołnierz straszliwy, któremu wszyscy ustąpić musieli, wdarł. Przelęknie się panna, a przedsię w łasce Bożej nie zwątpi, myśląc „,podomno [sic!] mię zabić przyszedł”. A on jej rzecze: „Nie bój się, siostro miła, na obronem twoję przyszedł, zachować, nie tracić chcę czystość twoję" [...]. I spełniło się Pismo: wilk z owca paść się pospołu będą. Oto wilk, oto owieczka: tak zgodnie i do ofiary Chrystusowej oboje sposobnie idą. [...] Uczyniła ś. tak [jak polecił jej żołnierz - E. C-B] Teodora: ubrała się jako żołnierz i twarz zasłoniwszy, uszła: jako ptak z sieci chytrych łowców [SkarŻyw 341].

${ }^{30}$ S. KobIElus, Bestiarium, s. 232, zob. też D. ForSTNER, Świat symboliki chrześcijańskiej, przeł. W. Zarzewska, Pachciarek, R. Turzyński, Warszawa 2001, s. 241; M. PARCHEM, Symbolika teriomorficzna $w$ żydowskich pismach apokaliptycznych okresu Drugiej Światyni na przyktadzie Ksiegi Daniela (Dn 7-8), Apokalipsy zwierzat (1 Hen 85-90) i Czwartej Ksiegi Ezdrasza (4 Ezd 11-12), „Studia Gdańskie” 2015, t. 36, s. 15-42.

${ }^{31}$ M. STRYJKOWSKI, Kronika, Królewiec 1582, s. 240. 
Dzięki interwencji „straszliwego żołnierza”, Didymusa, udaje się świętej oszukać prześladowców i zbiec. Cała sytuacja kończy się wręcz komicznie. Wszetecznicy, nie wiedząc o podstępie zastosowanym przez świętych, zastają w zamtuzie Didymusa w ubiorze Teodory. W finale pozostają z pustymi rękami, kompletnie zdezorientowani. Są przekonani, iż mają do czynienia z „czarami Chrystusa” i że Teodora zamieniła się w mężczyznę: „,co się dzieje? Z panny się stał mąż? Słyszałem, iż Chrystus z wody uczynił wino, pewnie i teraz z niewiasty uczynił męża. Uciekajmy, póki i z nas niewiast nie poczyni!" [SkarŻyw 341].

Inny biblijny motyw pojawia się jeszcze w żywocie św. Ruperta. Tutaj autor odwołuje się do słów Zbawiciela, który swym uczniom pozostawił takie zalecenie (Mt 10,16-17): „Oto Ja was posyłam jak owce między wilki. Bądźcie więc roztropni jak węże, a nieskazitelni jak gołębie!". Wąż w Starym Przymierzu miał wymowę dwoistą. Był niewątpliwie symbolem zła, uznawano go za inkarnację diabła (Księga Rodzaju) ${ }^{32}$. Gad ten oznaczał jednak także Boską Mądrość, zdolność uzdrawiania, a nawet stał się prefiguracją Mesjasza (Księga Liczb i scena wywyższenia przez Mojżesza miedzianego węża na pustyni) ${ }^{33}$. W Nowym Testamencie jest podobnie: serpens nadal funkcjonuje $\mathrm{w}$ aspekcie negatywnym (ewangelie, gdzie św. Jan ale i Jezus określają faryzeuszy mianem ,plemienia żmijowego", czy Apokalipsa, gdzie szatan jest wyobrażony jako smok-wąż starodawny), ale jest też emblematem roztropności. Tak samo jest w Żywotach. Obok przedstawień, gdzie wąż występuje jako ucieleśnienie Złego, mamy takie, jak żywot św. Ruperta, gdzie wybraniec Boży, wzorem Apostołów, posiada pożądane przymioty węża i gołębia [SkarŻyw 230]. Skarga nieprzypadkowo właśnie te cechy przypisuje świątobliwemu biskupowi, którego żywot stanowi unikat, gdyż nie znajdziemy $\mathrm{w}$ nim $\mathrm{w}$ zasadzie $\mathrm{w}$ ogóle miraculów, a jedynie relację z misji życiowej Ruperta, którą było nawracanie pogan i szerzenie chrześcijaństwa: w czym był podobny do uczniów Chrystusa. Święty był ponadto budowniczym świątyń, udało mu się także wznieść klasztor. Dzięki wężowym i gołębim przymiotom zjednywał sobie władców i z powodzeniem realizował swe posłannictwo.

Na uwage zasługuje jeszcze sylwetka Szymona Słupnika. Zasłynął on przede wszystkim z radykalnych (potępianych nawet przez przedstawicieli ówczesnej hierarchii kościelnej) metod udręczania ciała, uwagę przyciągało też nietypowe

${ }^{32}$ D. ADAmCZYK, Postać węża w opowiadaniu z Rdz 3, „Studia Koszalińsko-Kołobrzeskie” 2010, t. 15, s. 5-34; M. LURKER, Stownik obrazów i symboli religijnych, przeł. K. Romaniuk, Poznań 1989, s. 256 n.

${ }^{33}$ Ł. NIESIOŁOWSKI-SPANÒ [rec.], Biblijny kult węża-addenda (w zwiazku z artykułem Macieja Münnicha „Biblijny kult węży - próba interpretacji”, PH, t. XCV, 2004, z. 2, s. 153167), „Przegląd Historyczny” 96(2005), nr 4, s. 607-616. 
miejsce jego przebywania (przez całe lata mieszkał na słupie). Skarga, choć niewątpliwie pełen podziwu dla Szymona, to jednak przestrzega wiernych przed naśladowaniem go. Opisuje stylitę za pomocą rozbudowanej metafory, w której przyrównuje go do ptaka:

Prawym murem jest i świetnym słupem nie tylo jednemu miastu, ale wszytkiemu Kościołowi Bożemu ten dziwny słupnik, powietrzny męczennik, ziemski w ciele anioł, ptak duchowny ziemie się i pomazania jej nie dotykający. Którego tak wysoko latającego ledwie dojrzeć możem, poścignąć nie możem. Bo tych dwu skrzydeł nie mamy, którymi się on tak wysoko na takie cnoty wznosił, to jest tak wielkiej chęci i miłości ku Bogu i tak wielkiej i osobnej łaski Jego na tak cudowny żywot. [...] Przetoż kto by się o taki żywot kusił, jaki tu widzi, [...] niepomału by pobłądził [...] i mordercą by sam sobie został. Wedle wzrostu jest suknia, a małemu rosłego pachołka szata nie służy [SkarŻyw 31-32].

Metafora ta trafnie opisuje $\mathrm{z}$ jednej strony sposób życia świętego (w powietrzu łączonym z ptakami), z drugiej - doskonale uwydatnia charakter jego cnót: miłość ku Bogu i „chęć”, którą należy tu rozumieć nie tyle jako „ochotę na coś, pragnienie czegoś”, ile raczej jako „odwagę, zapał”, tu tożsame być może z męstwem ${ }^{34}$. Skarga te dwie cnoty uznaje za „skrzydła” duchownego ptaka, to co wyróżnia Symeona spośród innych ludzi i co przesądza o tym, iż jest on w owych cnotach niedościgniony. Oprócz przenośni mamy w cytowanym fragmencie jeszcze ciekawe określenie, które pojawia się w tekście Żywotów kilka razy: „ziemski w ciele anioł”. Także ono uwydatnia niezwykły - „dziwny” "35 stan świętego, którego charakteryzuje przynależność do dwóch światów: ziemskiego i niebieskiego.

Zwierzęta przedstawione w Żywotach w sposób dosłowny, pojawiają się głównie w historiach o męczennikach i pustelnikach. Wyjątki stanowią żywoty św. Teodora, który był żołnierzem, oraz Franciszka - zakonnika żyjącego we wspólnocie braci.

\footnotetext{
${ }^{34}$ Hasło Chęć, w: Słownik polszczyzny XVI wieku, wersja elektroniczna: http://spxvi.edu.pl /indeks/haslo/45791\#znaczenie-1

${ }^{35}$ Przymiotnik ,dziwny” może semantycznie łączyć się z niezaświadczonym w polszczyźnie XVI-wiecznej - ,atopiczny”. Zob. A. RAUBo [rec.], „Filozofii sq dziwacy, surowi, melankolicy...”: o atopicznych cechach osobowości filozofów w literaturze polskiego renesansu, „Pamiętnik Literacki” 99(2008), z. 3, s. 57-86.
} 
Związek męczenników i zwierząt wydaje się oczywisty: święci, którzy złożyli swe życie w ofierze za wiarę, często byli rzucani na pożarcie rozmaitym bestiom (zwykle były to lwy, niedźwiedzie - ogólnie rzecz biorąc - duże drapieżniki). Co istotne, nie obwiniali oni zwierząt o to, że muszą ponieść śmierć, przeciwnie. Jak powiadał Ignacy Antiocheński: „Blisko miecza to blisko Boga, razem ze zwierzętami to razem z Bogiem, byleby tylko w imię Jezusa Chrystusa"36. Przypadek eremitów jest bardziej złożony; dość często korzystają oni z różnych posług „braci mniejszych”, ale ich związki ze zwierzętami są w dziele kaznodziei ukazywane i na inne sposoby. Oba typy opowieści (tj. o męczennikach i o pustelnikach) łączy to, że „nieme twarze” są w nich prezentowane jako byty czujące, inteligentne nie tylko „na swój sposób”, ale czasem rozumnością przewyższające ludzi. To sprawia, że historie te są wzruszające. Fragmenty, w których jest ukazana współpraca ludzi i zwierząt, są nośnikiem też innych niż tylko perswazja funkcji. Skłaniają mianowicie do refleksji na tematy kluczowe, jak choćby wspomniana na wstępie wyższość człowieka nad innymi stworzeniami, zdolności poznawcze ludzi i zwierząt, a także ukazują, iż tylko żyjąc w harmonii ze światem roślin i zwierząt, nie zaś na drodze brutalnego ich podporządkowania, człowiek może osiągnąć szczęście i najwyższy stopień duchowego rozwoju - świętość. Chciałabym to raz jeszcze podkreślić: harmonijna koegzystencja ze światem przyrody, zasada niekrzywdzenia innych (w tym zwierząt) zasadniczo jest, w świetle Żywotów, jednym z warunków koniecznych, by dostąpić świętości. Byłyby więc Żywoty traktatem ekologicznym? Z pewnością takie stwierdzenie nie jest prawdziwe, ponieważ dzieło to nie tym zagadnieniom zostało poświęcone i nie taka jest jego nadrzędna funkcja ${ }^{37}$, ale warto zwrócić uwagę na to, jak został w nich przedstawiony świat przyrody - choćby po to, by zrewidować wspomniane stereotypy, które narosły wokół interpretacji Biblii, zwłaszcza zaś Księgi Rodzaju. W świetle owych stereotypów chrześcijaństwo nie respektuje zasad ochrony życia innych stworzeń i traktuje je instrumentalnie, gdyż są ontologicznie niższe (lege: gorsze). Taki pogląd jest niesłuszny i widać to na przykładzie tekstów takich, jak Żywoty, gdzie model świętości łączy się z poszanowaniem stworzonego przez Boga świata ${ }^{38}$.

36 Pierwsi świadkowie, tłum. A. Świderkówna, oprac. M. Starowieyski, Kraków 1978, s. 137. Zob. też E. WiPSZYCKA, M. StarowIEYSKI, Męczennicy, Kraków 1991.

${ }^{37}$ Cel swej pracy objaśnił Skarga we wstępnych częściach dzieła, zwłaszcza zaś w Przedmowie do Czytelnika.

${ }^{38}$ Wątek ten rozwija J. Salij, zob. TEGOŻ, Szukajacy drogi, dokument w wersji elektronicznej: http://mateusz.pl/ksiazki/js-sd/Js-sd_57.htm 
Podobieństwo ludzi i zwierząt w planie fizycznym expressis verbis wyraża już Stary Testament. Księga Koheleta nie pozostawia złudzeń co do sposobu śmierci jednych i drugich: „Przetóż jednakie jest dokończenie człowieka i bydląt i równy stan obojga. Jako umiera człowiek, tak i one umierają, i jednako tchną wszystkie, i nie ma człowiek nic więcej nad bydlę: wszytko podległo marności i wszytko idzie na jedno miejsce" (Koh 3,19-20). Pewną konsolację znajdziemy natomiast w Księdze Psalmów, gdzie pojawia się wizja odkupienia wszystkich stworzeń: „ludzie i bydlęta zbawisz, Panie” (Ps 35,7). W dobie średniowiecza, a potem i renesansu (a zatem także w czasie, kiedy powstawały Żywoty) wielką popularnością cieszyła się, mająca pogańskie korzenie, a później schrystianizowana, koncepcja o korespondencji makroi mikrokosmosu ${ }^{39}$. Główne podwaliny pod tę ideę położyli Platon (Timajos) i Arystoteles ( $O$ niebie $)$. Ich prace wpłynęły na całokształt wyobrażeń kosmologicznych i antropologicznych wieków średnich i Odrodzenia. Wielcy filozofowie Kościoła - jak np. Augustyn czy Tomasz z Akwinu, uznawali, podobnie jak antyczni poprzednicy, że każde stworzenie posiada duszę ${ }^{40}$. Mimo widocznych różnic i wyraźnego rozgraniczenia natury człowieka i zwierząt, dostrzegali też ich cechy wspólne ${ }^{41}$. Podkreślali, że człowiek jest podobny do zwierząt $w$ planie fizycznym oraz duchowym (ciało złożone $\mathrm{z}$ żywiołów i obecność pierwiastka zmysłowego w duszy ludzkiej i zwierzęcej), choć i jednocześnie od nich odmienny (widać to chyba bardziej u Tomasza, który np. zakłada śmiertelność duszy zwierzęcej) ${ }^{42}$. Różnica jednak zasadnicza polegała na tym, że tylko człowiek jest stworzeniem racjonalnym, wyposażonym w pamięć i posługującym się mową ${ }^{43}$. Także w koncepcji Hildegardy z Bingen człowiek został przedstawiony jako mikrokosmos: ponieważ jednoczył, jak twierdziła autorka Scivias, w sobie wszystkie stworzenia, wszystkie sposoby istnienia (homo omnis creatura). Człowiek jest (w jakiś sposób)

\footnotetext{
${ }^{39}$ Chrystianizacji pogańskich wyobrażeń o świecie, w tym idei mikrokosmosu w myśli chrześcijańskiej, poświęciłam wstępne rozdziały swojej książki (zob. przypis 8).

${ }^{40}$ T. STĘPIEŃ, Wprowadzenie do antropologii filozoficznej Tomasza z Akwinu, Warszawa 2013, s. 50 n.

${ }^{41}$ M. KRASNODĘBSKI, Dusza i ciało. Zagadnienie zjednoczenia duszy i ciała $w$ wybranych tekstach Tomasza z Akwinu oraz w filozofii tomistycznej, Warszawa 2004, s. 23-50.

42 Zob. D. NowAKowski, Św. Augustyn a paradoks zła, „Acta Universitatis Lodziensis”, Folia Philosophica 2010, nr 23, s. 79-80; zob. Św. Augustyn, Objaśnienia Psalmów. Ps 3757, w: Pisma Starochrześcijańskich Pisarzy, t. XXXVIII, przeł. J. Sulowski, oprac. E. Stanula, Warszawa 1986, s. 325-326.

${ }^{43}$ T. SAHAJ, Poglady Augustyna na temat śmierci, „Lingua ac Communitas” 1999, t. 9, s. 212.
} 
i rośliną, i zwierzęciem, i aniołem. I właśnie to jest fundamentem jego przynależności do stworzonego przez Boga uniwersum, to sprawia, iż byt ludzki dostrzega jego piękno, harmonię i jest zdolny odczuwać jedność $\mathrm{z}$ innymi stworzeniami, utożsamiać się z nimi (zgodnie z prawidłami myślenia alegorycznego i symbolicznego). Ta idea była bliska pustelnikom, którzy, jak konstatuje Małgorzata Borkowska ${ }^{44}$, choć wybierali na miejsce swego życia przestrzeń skrajnie nieprzyjazną (pierwsi eremici rzeczywiście mieszkali na pustkach, tj. pustyniach), to jednak marzyli o przywróceniu pierwotnej, rajskiej jedności człowieka z wszelkim stworzeniem.

Oczywiście - nie było to regułą: wśród pierwszych zapisów znajdujemy i takie, które przedstawiają „nieme twarze” jako zagrożenie. Pamiętajmy jednak, iż historie te powstały na pustyni, gdzie trudno o spotkanie ze stworzeniami uznawanymi za przyjazne, łatwiej spotkać tam jadowite stwory: żmiję rogatą czy skorpiona niż zwierzę o łagodnym usposobieniu. $\mathrm{Z}$ tego powodu część z relacji Ojców opowiada przede wszystkim o tym, jak przeżyć wśród takich bestii, część zaś to świadectwa mające na celu ukazać, że mnich doskonały może bez obawy brać w ręce wszelkie węże i skorpiony, a nawet unieszkodliwiać je pozbawiając życia poprzez rozcięcie nożem. Inne przekazy - także mające poświadczać świętość pustynnych mężów - opisują konfrontację z dzikimi bestiami inaczej, w sposób neutralny, choć jeszcze eksponujący przewagę człowieka nad zwierzęcym przeciwnikiem. Oto drapieżniki takie jak hieny czy też lwy ustępują miejsca pragnącym zamieszkać w ich legowiskach mnichom. Widzieli oni $\mathrm{w}$ tym zachowaniu bestii znak Bożej opieki i dowód na to, że zwierzęta wyczuwają Stwórcę w Jego wybrańcach. Wreszcie w Apoftegmatach znajdziemy i takie opowieści, gdzie człowiek i zwierzę współdziałają w jednym celu, jakim jest przywrócenie Raju na ziemi. Mamy zatem historie o tym, jak św. Gerazym ${ }^{45}$ oswoił lwa, który przez lata trwał przy swoim panu, zaś po jego śmierci umarł na jego grobie, czy o pustelniku i lwie zamieszkujących w jednej jamie. Tego rodzaju opisy harmonijnej koegzystencji ludzi i zwierząt znajdziemy i w Żywotach. Co więcej, u Skargi obraz zwierząt (tych opisywanych dosłownie, jako takie, nie zaś będących alegoriami czy symbolami) jest zawsze pozytywny. Nie znajdziemy zatem zapisów walki ludzi z dzikimi kreaturami i odwrotnie: bestie zachowują się

\footnotetext{
${ }^{44}$ M. BorkowsKa, Motyw Raju odzyskanego w apoftegmatach Ojców Pustyni (Pustelnicy i zwierzęta), „Vox Patrum” 8(1988), z. 15, s. 951-960. Opowieści z Apoftegmatów i innych pism Ojców referuję za tym artykułem.

${ }^{45} \mathrm{~W}$ późniejszej wersji tej legendy występuje nie św. Gerazym, a Hieronim, zob. M. BoRKOWSKA, Motyw Raju, s. 957.
} 
przyjaźnie wobec świętych. Nawet te uznawane jeszcze w tradycji patrystycznej za złe, jak np. wąż, służą Bożym wybrańcom, okazują im respekt. Jest to novum w porównaniu z opowieściami Ojców Pustyni, którzy, jak stwierdza Borkowska, choć chętnie przyjaźnili się ze zwierzętami, to jednak nie mogli przemóc swego wstrętu wobec węży. Badaczka wspomina, że mieli oni nawet problem z tym, aby uznać całość wizji Izajasza, który w zbiorze stworzeń odkupionych, przebywających w przywróconym Raju, umieścił także obrzydłego gada. W Żywotach wąż nie występuje jako odrzucony, nie jest w żaden sposób gorszy od pozostałych członków boskiego zwierzyńca i może być stworzeniem sprzyjającym sługom Bożym. W żywocie Piotra Celestyna, pustelnika i papieża, czytamy:

z Rzymu wyszedłszy [gdzie odebrał święcenia - E. C-B], a pustyniej jeszcze pragnąc, w górze Muronis skałę jednę wydrazżoną nalazł, którą sobie za mieszkanie obrał. Z niej wielki wąż wylazłszy, miejsca mu ustąpił i gościa uczcił. W tej skale pięć lat przemieszkał [SkarŻyw 471].

Eremitą, który potrafił nakłonić dzikie zwierzę do współpracy, był św. Gaweł zwany też Gallusem, tj. Kogutem. Imię to wiąże się ze zdolnością panowania Gawła nad nieczystymi duchami. Kur był tradycyjnie uznawany za ptaka zwiastującego nadejście poranka, łączono go ze słońcem, a przez to z Chrystusem. Uważano, że kogut (w interpretacji alegorycznej - Chrystus) to odwieczny wróg bazyliszka (szatana), co odzwierciedla się także w historii Skargi. Podczas wędrówki przez las Gaweł poskromił groźnego niedźwiedzia. Mocą Boskiego nakazu skłonił go do tego, by pomógł nosić drwa na ognisko. Kiedy zwierz wykonał pracę, święty ofiarował mu bochenek chleba (to bowiem zapach pożywienia wywabił bestię z gawry [SkarŻyw 946]). W żywocie Gawła odnajdujemy zatem wątki podobne do tych, które konstytuowały starsze opowieści Ojców Pustyni. Święty rozkazuje zwierzęciu, ma nad nim władzę, ale jednocześnie okazuje mu dobroć, dzieląc się z nim posiłkiem. W dziele jezuity więcej jest jednak historii innego typu, tj. takich, gdzie wybrańcy Boży nie tyle „rozkazuja”, jak Gaweł, ale zjednują sobie „bestyje” inaczej. Jak? Odpowiedź na to pytanie znajdujemy w żywocie św. Epifaniusza, któremu „bestyje” niszczyły ogród:

Nie czyńcie mi, powiada, przykrości. Jam człek grzeszny i nędzny, na tom miejsce przyszedł płakać za wielkość złości moich, aza mi je Bóg mój odpuści. Ten, który mi dał ty jarzynki na pożywienie, i Ten wam rozkazuje, abyście roboty mej nie psowali. Tymi słowy nigdy napotym bestyje żadnej szkody mu nie czyniły [SkarŻyw 453]. 
Co zwraca uwagę w przedstawionym tu akcie komunikacji między człowiekiem a zwierzętami? Sposób, w jaki Epifaniusz zwraca się do nich. Rozmawia ,jako z ludźmi”, traktuje jako godnych partnerów, a nawet uniża się, uznając swoją małość. Nie ma tu już miejsca na „rozkazy”: te bowiem wydaje (czy to zwierzętom, czy też ludziom) wyłącznie Bóg - Pan Stworzenia. Człowiek zaś może jedynie z pokorą prosić i tak też czyni bohater żywota.

Obok tych przykładów na uwagę zasługuje jeszcze żywot św. Teodora. Nie był on wprawdzie pustelnikiem, ale żołnierzem. Wraz ze swoim dzielnym koniem pokonał straszliwego smoka. Żywot stanowi znakomite exemplum potwierdzające, iż święci traktowali zwierzęta nie jako „narzędzia” służące do osiągnięcia zamierzonego celu, np. zdobycia autorytetu, ale widzieli w nich istoty w dużej mierze podobne do człowieka: odczuwające (jak ludzie) ból, strach, a nawet - na swój sposób racjonalne, przeczuwające Stwórcę i Jemu podporządkowane. Teodor nie zmusza zwierzęcia do posłuszeństwa, a jedynie ufa, że dzięki mocy Bożej zechce z nimi współdziałać [SkarŻyw 187]. Historia o zabiciu smoka przez świętego może się wydawać konwencjonalna, gdyż znane są podobne narracje o pokonaniu piekielnego gada przez Michała Archanioła czy też św. Jerzego. Trzeba jednak zaznaczyć, iż chronologicznie historia Teodora poprzedza tę o św. Jerzym, która powstała właśnie na kanwie żywotu męczennika z Euchaity ${ }^{46}$.

Modelowym przykładem koegzystencji ze światem natury jest też żywot św. Pawła Pustelnika. Święty ten pędził żywot rajski niczym pierwszy człowiek - Adam, w doskonale do tego przystosowanym miejscu. Poświadczaja to słowa innego wielkiego męża, św. Antoniego, który dał takie świadectwo o Pawle swoim współbraciom: „Widziałem Eliasza, widziałem Jana na puszczy, widziałem Pawła w Raju” [SkarŻyw 52]. Ów „Raj” został zobrazowany przez Skargę na początku żywotu, gdzie opisał on powołanie Pawła i jego decyzję o tym, by żyć w odosobnieniu. W Apoftegmatach Ojców Pustyni puszcza jawi się jako przestrzeń nieprzyjazna, którą mnisi winni sami czynić sobie Rajem na drodze przemiany własnej świadomości. Tutaj jednak mamy do czynienia z realizacją toposu locus amoenus: pustelnia to już nie pełen niebezpieczeństw obszar, ale miejsce, gdzie panują wystarczająco dobre warunki, aby przebywający tam mnich nie doznawał rozproszenia $\mathrm{z}$ powodu ewentualnych zagrożeń i mógł się całkowicie poświęcić kontemplacji ${ }^{47}$.

\footnotetext{
46 J. DE Voragine, Złota legenda. Wybór, przeł. J. Pleziowa, oprac. M. Plezia, Warszawa 1983, s. 206-210.

${ }^{47}$ A. KRZEWIŃSKA, Miejsca rozkoszne i miejsca straszne w tradycjach mitologiczno-religijnych, filozoficznych i literacko-retorycznych, w: Muzy i Hestia. Studia dedykowane Profesor
} 
Miejsce zamieszkania Pawła jest więc mierne: w sam raz - nie zanadto zbytkowne, ale też nie całkowicie ogołocone, niepozbawione jakichkolwiek dogodności [SkarŻyw 50].

Paweł na swój wzór obrał proroka Eliasza. Wybór ten musiał być zgodny z Bożą wolą, gdyż Pan udziela Pustelnikowi podobnych łask i związanych z nimi przywilejów. Jednym z przejawów tego stanu jest to, iż Bóg zsyła Pawłowi pokarm za pośrednictwem kruka: dokładnie w ten sam sposób był niegdyś żywiony przez Stwórcę wspomniany Eliasz ${ }^{48}$. Kiedy do Pawła przybywa Antoni, skrzydlaty posłaniec przynosi podwójną porcję chleba. Pustelnik wyjaśnia wówczas, iż ,już sześćdziesiąt lat jako mi ten ptak po pół bochenka co dzień nosi, a dziś dla gościa przyczynił Pan Bóg obroku i posłał żywność żołnierzom swoim" [SkarŻyw 51]. To niejedyny moment, w którym Bóg poświadcza wielkość Pawła za pośrednictwem stworzenia. Czyni to także w dniu jego pogrzebu:

A iż był motyki prze wielkie kwapienie $\mathrm{z}$ sobą wziąc zapomniał [Antoni E.C-B], zdała mu się wielka trudność i żałość. I płacząc nad onym ciałem „Cóż mam czynić, Panie mój - mówił. - Trzy dni chodzenia po motykę, niż z nią przyjdę, boję się, aby ciała zwierz nie stargał. Tu mieszkajacc, nic nie sprawię. Wolę tu przy straży ciała tego umrzeć, jeśli mię nie wspomożesz”. Na tę modlitwę posłał Pan Bóg dwu wielkich lwów, którzy przed jego oczyma dół dostateczny wygrzebli. W którym go uczciwie pogrzebwszy, do domu się do swych braciej wrócił i wszytkę rzecz dostatecznie opowiedział [SkarŻyw 52].

„Zwierz” nie tylko „ciała nie stargał”, ale przygotował grób dla tego, który żył $\mathrm{w}$ doskonałej harmonii z przyroda. Takich przypadków jest w dziele Skargi więcej. Dzikie bestie albo pomagają w pochówku, albo strzegą ciał świętych przed zbezczeszczeniem (zob. np. opowieści o św. Wojciechu oraz Florianie strzeżonych przez orły czy też Lucjanie, którego utopiono w morzu.

Ludwice Ślękowej, red. M. Cieński i J. Sokolski, Wrocław 1999; E.R. CuRTIUS, Literatura europejska i tacińskie średniowiecze, tłum. i oprac. A. Borowski, Kraków 1997, rozdział X: Krajobraz idealny, s. 193 n; J. ABRAMOWSKA, Topos i niektóre miejsca wspólne badań literackich, „Pamiętnik Literacki” 73(1982), z. 1-2, s. 15, 18; R. PrZYBYLSKI, Pustelnicy i demony, Kraków 1994, s. 37; J.W. KowALSKI, Świat mnichów i zakonów, Warszawa 1987, s. 87-90.

48 Zwraca uwagę polisemiczność kruka, który w tradycji biblijnej jawi się jako ptak nieczysty (żywi się bowiem padliną), z drugiej - to właśnie jemu Noe w pierwszej kolejności powierza zadanie sprawdzenia, czy wody potopu już opadają. Jako żywiciel Eliasza kruk staje się symbolem Bożej Opatrzności, i tak należy odczytywać jego symbolikę także w opisywanym żywocie. U Skargi ptak ten występuje także w znaczeniu negatywnym, jako figura heretyka, który wyleciawszy z Arki, tj. z Kościoła, nie wraca już do niego [SkarŻyw 270]. 
Został on potem wyniesiony na brzeg przez delfina, który po dokonaniu tego aktu zdechł). Ponadto „,bestyje” odmawiaja zjedzenia rzuconych im doczesnych szczątków Bożych wybrańców (np. żywot św. Gordyjana): chyba najbardziej osobliwą realizacją tego motywu jest scena z żywota świętych Prymusa i Feliciana, kiedy to ,nie tylko bestyje, ale i muchy dotknąć się ich nie chciały" [SkarŻyw 532]. Tego rodzaju oznaki swoistej czci świętych Bożych pojawiają się najczęściej w żywotach męczenników. To w tych opowieściach zwierzęta wydają się najbardziej nobilitowane. Autor opisuje często ów paradoks: „bestyje nierozumne” okazują się rozumnymi, to, co bestialskie i nieprzystojne człowiekowi - staje się jego udziałem, zaś zwierzęta stają się „ludzkie”. Leksem „ludzki” należy tu odczytywać w znaczeniu: “właściwy ludziom dobrym; przychylny, łaskawy, życzliwy, układny, uprzejmy (humanus) ${ }^{49}$. „Właściwy ludziom” - nie zaś bestiom. Tymczasem u Skargi porządek ten ulega odwróceniu. Oto przykład z żywotu św. Martyny:

Cesarz nie znając przez ślepotę swoję mocy Bożej, kazał pannę [św. Martynę] policzkować i żelaznymi hakami drapać tak długo, aż mordercy jej spracowani krzykną: „My sami męcząc ją, zmęczeni jesteśmy”. [...] A on ją zasię lwowi srogiemu na pożarcie podać kazał. Lecz lew u nóg się jej położył a ciała panieńskiego nie obraził, a wracając się do swej jamy, powinowatego cesarskiego zabił [SkarŻyw 20-21].

Podobne exemplum znajdziemy w opowieści o św. Tekli [SkarŻyw 885] czy żywocie św. Eustachiusza [SkarŻyw 879]. Osią każdego z tego typu obrazów jest kontrast i (jednocześnie) paradoks, skonstruowany na zasadzie inwersji. Ludzie zachowują się jak zwierzęta i na odwrót. Człowiek (z natury) jest stworzeniem rozumnym i zdolnym poznać (choćby tylko w ograniczonym stopniu) Boga. Tak się jednak nie dzieje, bowiem aby to stało się możliwe, konieczna jest zgoda jednostki na to, by Stwórca działał. Tutaj tej zgody nie ma. Jest jedynie „ślepota”, którą należy rozumieć metaforycznie, jako duchową oziębłość. Ludzie „składają człowieczeństwo” i „bestyjalstwo biorą na się": stają się okrutni i dopuszczają się największych, a w dodatku wyrafinowanych zbrodni, na jakie nie poważyłyby się nawet najdziksze bestie. Co jeszcze warte odnotowania, to fakt, iż nie tylko zwierzęta wyższe, jak niedźwiedzie, psy czy lwy występują w tych opowieściach jako „rozumne”, ale i stworzenia niższe - muchy (a w opowieści o św. Marku Aretuzjańskim też

\footnotetext{
${ }^{49}$ Hasło Ludzki, w: Stownik polszczyzny XVI wieku, wersja elektroniczna: http://spxvi.edu. pl/indeks/haslo/62429\#znaczenie-1
} 
pszczoły i osy), węże, skorpiony, bliżej nieokreślone „bestyje morskie żarłoczne” czy ,jaszczorki” - także są w tę świadomość wyposażone. Kaznodzieja ukazał to znów w żywocie Tekli, którą wrzucono do dołu wypełnionego wzmiankowanymi kreaturami, ale i one „więcej ją czcić się zdały, a niźli szkodę którą uczynić panieńskiemu ciału chciały" [SkarŻyw 868]. Podobną torturę zostosowano także względem św. Eufemii, wtrąconej do jamy z wężami, które jednak ,raczej ją na swych grzbietach nosiły, jakoby się o jej zdrowie starając" [SkarŻyw 886]. Te fragmenty należy uznać za szczególny przykład nobilitacji „bestyj nierozumnych”: w przytoczonych opowiadaniach nie tylko przypisane zostają im cechy ludzkie, ale są one rozwinięte w tak wysokim stopniu, iż zwierzęta przewyższają ludzi. Przeniesiona zostaje pewna aksjologiczna granica: byt do tej pory uznawany za niższy, teraz jawi się jako doskonalszy.

Wszystkie powyższe historie obrazują przyjaźń świętych ze zwierzętami - nawet w obliczu ostatniej próby. Nie zawsze jednak słudzy Boży wychodzą ze spotkania z drapieżcami cało: przywoływana św. Tekla w finale przypłaca to życiem. Odejście świętej nie następuje jednak w wyniku aktu prostej agresji ze strony „bydląt”. Znów działają one rozmyślnie, zgodnie z wolą Stwórcy. Nie jest to więc śmierć zadana w sposób okrutny, taki, który mógłby w jakikolwiek sposób umniejszyć bohaterstwo czy (tym bardziej) cześć Bożej służebnicy: „A potym jedna niedźwiedzica maluczką jej ranę w nodze zadała, od której panienka, mając już głos Boży do wyjścia z ciała, upadła i ducha wypuściła” [SkarŻyw 868]. Śmierć przychodzi łagodnie: to tylko „wyjście z ciała”, a życie ulatuje prędko i bezboleśnie przez „maluczką ranę”. Zwierzęta to nie agresorzy. Tymi są wyłącznie ludzie. „Bestyje” zaś są przewodnikami, pomagaja w przejściu „na lepszy żywot”, a tym samym, co wyraził cytowany wyżej św. Ignacy z Antiochii, prowadzą świętego do Boga:

Pozwólcie mi stać się żerem dzikich zwierząt, przez które mogę posiąść Boga. Pszenicą jestem Boga, a zmielony zwierzęcymi zębami, okażę się czystym chlebem Chrystusa. Raczej zachęcajcie zwierzęta, aby stały się dla mnie grobem i nie pozostawiły nic z ciała mego.... Błagajcie za mnie Chrystusa, abym z pomocą zwierząt stał się ofiarą dla Boga ${ }^{50}$.

Dopełnieniem i jednocześnie zwieńczeniem wszystkich przytoczonych tu fragmentów Skargowego dzieła jest oczywiście żywot św. Franciszka. I choć jezuita więcej miejsca poświęca deskrypcji duchowej ścieżki „biedaczyny

\footnotetext{
${ }^{50}$ Zob. Pierwsi świadkowie, s. 191.
} 
Bożego", niż opisowi jego relacji ze światem przyrody, to jednak właśnie wzmianka o wyjątkowej relacji Franciszka z „braćmi mniejszymi” stanowi bodajże najbardziej urzekający i stylistycznie kunsztowny ustęp całego żywotu. Język tego fragmentu jest niezwykle bogaty w środki wyrazu (w tym liczne formy deminutywne, zaświadczające o emocjonalnym zabarwieniu wypowiedzi), pojawiają się dynamiczne opisy, rozliczne wyliczenia. Jedność wszystkich stworzeń wspomnianych przez Skargę, podkreśla zresztą sam staropolski język, którego system gramatyczny nie wprowadzał jeszcze ścisłego rozgraniczenia na świat ludzi i zwierząt:

Bestyje nieme bracią swoją i siostrami z wielkiej łaskawości zwał. [...] Zajączkowie do niego się od inych uciekając cisnęli, ptaszkowie, gdy kazał, do niego lecieli. Raz wszedł między stado ptaków śpiewajacych, a żaden się nie ruszył, a gdy z bracią mówić tam pacierze począł, a słyszeć się przez wrzask ptaków nie mogli, rzekł św. Franciszek: „Bracia ptaszkowie, umilknijcie, aż się ze służbą Bożą odprawiem”. Wszyscy umilknęli i nie poczęli śpiewać, aż im kazał. [...] Z każdego stworzenia umiał się ku więtszej miłości Boskiej pobudzić [SkarŻyw 920].

Wszystkie zacytowane tu exempla mogą się wydać oczywiście naiwnymi historyjkami: i tak właśnie przez długi czas były interpretowane przez badaczy literatury, historyków ${ }^{51}$, o czym wspominałam już kilkakrotnie w innych swoich pracach. Dopiero dogłębna - inspirowana mikrologią - analiza tych motywów pozwala wydobyć ich prawdziwy blask i wagę. Figury zwierząt czy to ukazywane jako symbole vel alegorie, czy też potraktowane dosłownie, są w Żywotach nośnikami ważnych komunikatów, które w niniejszej pracy starałam się zrekonstruować. Na przekór utartym uprzedzeniom i stereotypom, których rozpoznania i rewizji dokonuje współczesne literaturoznawstwo.

\section{BIBLIOGRAFIA}

ABRAMOWSKA J.: Topos i niektóre miejsca wspólne badań literackich, „Pamiętnik Literacki” 73(1982), z. 1-2, s. 3-23.

ADAMCZYK D.: Postać węża w opowiadaniu z Rdz 3, „Studia Koszalińsko-Kołobrzeskie” 2010, t. 15 , s. 5-34

${ }^{51}$ Zob. np. J. TAZBIR, Piotr Skarga. Szermierz kontrreformacji, Warszawa 1978, s. 104107, 111; H. BARYCZ, Z dziejów jednej ksiażki, w: TEGOŻ, Z epoki renesansu, reformacji i baroku. Prady, idee, ludzie, ksiażki, Warszawa 1971, s. 656-657. 
AlEKSIEJUK A.: „Homilie na sześć dni stworzenia” świętych Bazylego Wielkiego i Ambrożego z Mediolanu: przyczynek do analizy porównawczej „Hexaemeronów”, „Acta Patristica” 9(2018), z. 18, s. 56-72.

BARYCZ H.: Z dziejów jednej książki, w: TEGOŻ, Z epoki renesansu, reformacji i baroku. Prądy, idee, ludzie, książki, Warszawa 1971.

BAtTistini M.: Astrologia, magia, alchemia. Leksykon historia, sztuka, ikonografia, przeł. E. Morka, Warszawa 2006.

BorkowsKA M.: Motyw Raju odzyskanego w apoftegmatach Ojców Pustyni (Pustelnicy i zwierzęta), „Vox Patrum” 8(1988), z. 15, s. 951-960.

Chevalier J., Gheebrant A.: Dictionaire des symboles: mythes, rêves, coutumes, gestes, formes, figures, coloreurs, nombres, Paryż 1982.

CuRTIUs E.R.: Literatura europejska i łacińskie średniowiecze, tłum. i oprac. A. Borowski, Kraków 1997.

CYBULSKA-BOHUSZEwiCz E.: „On utwierdził na wieki niebo niestanowne”. Chrześcijańska wizja kosmosu w poezji polskiej (od połowy XVI do połowy XVIII w.), Warszawa 2010.

Dominikanie w czasach krucjat, katedr i herezji, red. T. Gałuszko, M. Karp, Poznań 2016.

Dominikanie w środkowej Europie w XIII-XV wieku: aktywność duszpasterska i kultura intelektualna, red. J. Kłoczowski, J.A. Spież, Poznań 2002.

FERGUSON G.: Signs \& Symbols in Christian Art, London-Oxford 1989.

FORSTNER D.: Świat symboliki chrześcijańskiej, przeł. W. Zarzewska, P. Pachciarek, R. Turzyński, Warszawa 2001.

HANUSIEWICZ M.: Święte i zmysłowe w poezji religijnej polskiego baroku, Lublin 1998.

JASKÓŁA P.: Bóg rzekł i stało się. Zarys patrologii, Opole 2018.

JORDAN Z SAKSONII: Książeczka o początkach Zakonu Kaznodziejów, przeł. M. Wylęgała, wstępem i przypisami opatrzył J.A. Spież, Warszawa 2008.

KobieluS S.: Bestiarium chrześcijańskie. Zwierzęta w symbolice i interpretacji: Starożytność i średniowiecze, Warszawa 2002.

KOPALIŃSKI W.: Słownik symboli, Warszawa 2001.

KOWALSKI J.W.: Świat mnichów i zakonów, Warszawa 1987.

KrasnodębSKI M.: Dusza i ciało. Zagadnienie zjednoczenia duszy i ciała w wybranych tekstach Tomasza z Akwinu oraz w filozofii tomistycznej, Warszawa 2004.

KRZEWIŃSKA A.: Miejsca rozkoszne i miejsca straszne w tradycjach mitologiczno-religijnych, filozoficznych i literacko-retorycznych, w: Muzy i Hestia. Studia dedykowane Profesor Ludwice Ślękowej, red. M. Cieński i J. Sokolski, Wrocław 1999.

KWAPISZEWSKA-ANTAS M.: Człowiek wobec zwierząt na przestrzeni dziejów, „Słupskie Studia Filozoficzne" 2007, nr 6, s. 97-110.

LÉvi-Strauss C.: Totemizm, przeł. A. Steinsberg, Warszawa 1968.

LURKER M.: Słownik obrazów i symboli religijnych, przeł. K. Romaniuk, Poznań 1989.

MARECKI J., RotTer L.: Jak czytać wizerunki świętych. Leksykon atrybutów i symboli hagiograficznych, Kraków 2009.

MAYENOWA M.: O kilku staropolskich formach ekspresywnych. Z materiałów „Słownika polszczyzny XVI w.”, „Pamiętnik Literacki” 1966, nr 4, s. 485-490.

NAWARECKI A.: [Wstęp do:] Miniatura i mikrologia literacka, t. I-III, red. A. Nawarecki, Katowice 2000-2003.

NAWARECKI A.: O śląskiej szkole mikrologii (1999-2005). Garść wspomnień, „Forum Poetyki” 2017, s. 13. http://fp.amu.edu.pl/o-slaskiej-szkole-mikrologii-1999-2005-garsc-wspomnien/

NeHring P.: Topika wczesnych łacińskich żywotów świętych. Od „Vita Antonii” do „Vita Augustini”, Toruń 1999. 
NIESIOŁOWSKI-SPANÒ Ł. [rec.]: Biblijny kult węża-addenda (w związku z artykułem Macieja Münnicha „Biblijny kult węży - próba interpretacji”, PH, t. XCV, 2004, z. 2, s. 153-167), „Przegląd Historyczny” 96(2005), nr 4, s. 607-616.

NowAKOWSKI D.: Św. Augustyn a paradoks zła, „Acta Universitatis Lodziensis”, Folia Philosophica 2010, nr 23, s. 61-88.

PARCHEM M.: Symbolika teriomorficzna w żydowskich pismach apokaliptycznych okresu Drugiej Świątyni na przykładzie Księgi Daniela (Dn 7-8), Apokalipsy zwierząt (1 Hen 85-90) i Czwartej Księgi Ezdrasza (4 Ezd 11-12), „Studia Gdańskie” 2015, t. 36, s. 15-42.

Pierwsi świadkowie, tłum. A. Świderkówna, oprac. M. Starowieyski, Kraków 1978

PRZYBYLSKI R.: Pustelnicy i demony, Kraków 1994.

PRZYBYŁA W.: Kulturowa semantyka motywu zwierząt, „Teksty Drugie” 2011, nr 3, s. 238-252.

Raubo A. [rec.]: „Filozofii są dziwacy, surowi, melankolicy...” o atopicznych cechach osobowości filozofów w literaturze polskiego renesansu, „Pamiętnik Literacki” 99(2008), z. 3, s. 57-86.

SAHAJ T.: Poglądy Augustyna na temat śmierci, „Lingua ac Communitas” 1999, t. 9, s. $211-222$

Skala mikro w badaniach literackich, red. A. Nawarecki, M. Bogdanowska, Katowice 2005.

SimONeTti M.: Między dosłownością a alegorią. Przyczynek do historii egzegezy patrystycznej, przeł. T. Skibiński, Kraków 2000.

STĘPIEN T.: Wprowadzenie do antropologii filozoficznej Tomasza z Akwinu, Warszawa 2013.

SzCZEPANOwICZ B.: Zwierzęta i rośliny w życiu świętych oraz jako ich atrybuty, Kraków 2007.

TAZBIR J.: Piotr Skarga. Szermierz kontrreformacji, Warszawa 1978.

WiPSZYCKa E., STAROWIEYSKi M.: Męczennicy, Kraków 1991.

Zgraja B.: Stworzenia nierozumne wezwaniem do doskonałości. Przyczynek do studium nad „Hexaemeronem” św. Ambrożego, „Vox Patrum” 32(2012), t. 57, s. 821-836.

\author{
,Z KAŻDEGO STWORZENIA \\ UMIAŁ SIE KU WIETSSZEJ MIŁOŚCI BOSKIEJ POBUDZIĆ”, \\ ZWIERZĘTA JAKO PRZYJACIELE SŁUG BOŻYCH \\ (NA PODSTAWIE ŻYWOTÓW ŚWIĘTYCH PIOTRA SKARGI)
}

\title{
St reszcze ni e
}

Artykuł stanowi analizę motywów zwierzęcych występujących w Żywotach świętych P. Skargi. Mogłoby się wydawać, że nie pełnią one istotnej roli w monumentalnym przecież dziele. Jednak kiedy zwrócimy na nie baczniejszą uwagę, okazuje się, że są nośnikami cennych informacji, związanych z tym, w jaki sposób na gruncie chrześcijaństwa kształtowały się poglądy dotyczące miejsca człowieka i zwierząt we wszechświecie. Analiza zebranych w artykule motywów ukazuje, że nie mają racji bytu rozpowszechnione (zwłaszcza w ostatnim czasie) stereotypy, wynikające głównie z błędnego odczytania biblijnej frazy: „Czyńcie sobie ziemię poddaną", w świetle których chrześcijaństwo jako religię już od samego początku cechować miał jakoby brak szacunku do stworzonego świata i instrumentalne podejście do zwierząt. Podobnie błędne jest przeświadczenie, że przyjazne relacje z „braćmi mniejszymi” miał tylko św. Franciszek z Asyżu, zaś inne święte osoby nie były związkami z nimi zainteresowane. 
Prezentowany tekst metodologicznie nawiązuje do ustaleń tzw. śląskiej „szkoły” mikrologii, a zatem zakłada skupienie się na tych częściach badanego dzieła, które są uznawane za fragmenty, odpryski, słowem - ,miniatury” - komunikaty, które (na pierwszy rzut oka) nie przesadzają o jego wartości. Studium stanowi dopełnienie artykułu „Znać iżeście i bestyj podlejszy”: zoomorficzne inkarnacje szatana $w$ „Żywotach świętych” Piotra Skargi, który został opublikowany w czasopiśmie „Terminus” (2/2019).

Słowa kluczowe: świętość; zwierzęta; natura; hagiografia; patrologia; mikrologia.

\author{
„EACH CREATURE INSPIRED TO GREATER GOD'S LOVE”: \\ ANIMALS AS FRIENDS OF GOD'S SERVANTS \\ (ON THE BASIS OF PIOTR SKARGA'S ŻYWOTY ŚWIEূTYCH)
}

\title{
S u m m a r y
}

This article is an analysis of the animal motifs in Piotr Skarga's Żywoty świętych [The Lives of the Saints]. It might initially seem that they do not play an important role in this monumental work. However, when we pay more attention to them, it turns out that they convey valuable information related to the way in which views on the place of man and animals in the Christian universe were formed. An analysis of the motifs collected in the article shows that there is no justification for those stereotypes which result mainly from an erroneous interpretation of the biblical phrase: „Be fruitful and multiply and fill the earth and subdue it”, according to which, from the very beginning, Christianity as a religion was supposed to be characterised by a lack of respect for the created world and a merely instrumental approach to animals. Similarly, the conviction that only St. Francis of Assisi had a friendly relationship with „friars minor", while other saints were not interested in relationships with them, is also erroneous. The presented text methodologically refers to the findings of the so-called Silesian "school" of micrology, and therefore it aims to concentrate on those parts of the examined work which are considered to be fragments, scraps or „miniatures” - messages that (at first glance) do not determine its value. The present study supplements the article „Znać iżeście i bestyj podlejszy”: zoomorficzne inkarnacje szatana $w$,Żywotach świętych” Piotra Skargi published in the journal Terminus (2/2019).

Key words: sacred; animals; nature; hagiography; patristics; micrology.

Translated by Rafat Augustyn 